\author{
Robert SMUSZ ${ }^{1}$ \\ Joanna WILK ${ }^{2}$ \\ Pawel GIL ${ }^{3}$ \\ Maria TYCHANICZ-KWIECIEN' ${ }^{4}$ \\ Pawel BALON ${ }^{5}$
}

\title{
BADANIA TERMOFIZYCZNE MATERIAŁÓW ZMIENNOFAZOWYCH W ASPEKCIE ICH ZASTOSOWAŃ W UKŁADACH DO ODZYSKU CIEPLA ODPADOWEGO
}

\begin{abstract}
W artykule zaprezentowano wyniki badań eksperymentalnych właściwości termofizycznych wybranych materiałów zmiennofazowych PCM (ang. Phase Change Material). Znajomość właściwości cieplnych materiałów zmiennofazowych jest niezbędna przy projektowaniu urządzeń akumulujących ciepło lub układów do odzysku ciepła odpadowego. Opracowywana koncepcja takiego urządzenia pracującego dodatkowo w układzie z odzyskiem ciepła odpadowego była podstawą do prowadzonych badań. W ramach pracy zostały wykonane pomiary przewodności, dyfuzyjności cieplnej, ciepła właściwego oraz gęstości. Badane materiały to: wosk plastyczny, cerezyna niskotopliwa oraz ksylitol i erytrytol. Do badań właściwości cieplnych materiałów zastosowano metodę gorącego drutu.
\end{abstract}

Słowa kluczowe: materiał zmiennofazowy, ciepło właściwe, przewodność cieplna, dyfuzyjność cieplna

\section{Wprowadzenie}

Akumulacja ciepła jest kluczowym procesem poprawiającym skuteczność wykorzystania energii cieplnej, a zastosowanie w praktyce systemów akumulujących ciepło jest obecnie bardzo szerokie. Spośród znanych metod akumulacji energii cieplnej szeroko stosowane są metody wykorzystujące akumulację ciepła utajonego, wyzwalającego się w wyniku zajścia przemiany fazowej. W ostatnich

\footnotetext{
1 Autor do korespondencji/corresponding author: Robert Smusz, Politechnika Rzeszowska, al. Powstańców Warszawy 8, 35-959 Rzeszów, tel.: (17) 8651288, e-mail: robsmusz@prz.edu.pl

2 Joanna Wilk, Politechnika Rzeszowska, e-mail: wilkjoan@prz.edu.pl

${ }^{3}$ Maria Tychanicz-Kwiecień, Politechnika Rzeszowska, e-mail: mtychanicz@prz.edu.pl

${ }^{4}$ Paweł Gil, Politechnika Rzeszowska, e-mail: gilpawel@prz.edu.pl

${ }^{5}$ Paweł Bałon, SZEL-TECH, Mielec, e-mail: balonpawel@gmail.com
} 
latach dostrzeżono znaczny potencjał wykorzystania materiałów PCM (ang. Phase Change Materials) w procesach akumulacji ciepła. Materiały zmiennofazowe to substancje o znacznej wartości utajonego ciepła przemiany fazowej [1]. Materiały te mogą absorbować, akumulować oraz uwalniać duże ilości energii w zakresie temperatur przemiany fazowej. Można je podzielić na związki organiczne, nieorganiczne oraz mieszaniny eutektyczne. Wśród organicznych materiałów PCM można wyróżnić parafiny, kwasy tłuszczowe, estry, glikole. Do nieorganicznych materiałów PCM zalicza się natomiast uwodnione sole, metale i stopy (siarczan sodu, boraks, sześciowodny chlorek wapnia) [2].

Spośród najważniejszych parametrów termofizycznych materiałów zmiennofazowych należy wymienić temperaturę przemiany fazowej, ciepło właściwe, pojemność cieplną oraz wartość współczynnika przewodzenia ciepła [3]. Przy wyborze odpowiedniego materiału należy brać pod uwagę stabilność właściwości, toksyczności, bezpieczeństwo, palność oraz względy ekonomiczne [4]. Akumulacja ciepła z wykorzystaniem materiałów zmiennofazowych należy do metod stosowanych w systemach wysokotemperaturowych, które są użyteczne głównie w technologiach wykorzystujących odnawialne źródła energii (OZE), odzysku ciepła odpadowego oraz w energetyce [1-5].

Odzysk ciepła odpadowego może się odbywać na szeroką skalę - od zakładów przemysłowych, elektrowni konwencjonalnych i wykorzystujących OZE, po urządzenia chłodnicze i klimatyzacyjne. W przypadku wykorzystania ciepła odpadowego ze źródeł chłodniczych czy klimatyzacyjnych istnieje potrzeba jego akumulacji. Do odzysku ciepła są wykorzystywane zbiorniki akumulacyjne na ciepłą wodę użytkową. W zbiornikach tych umieszcza się dodatkowe elementy wykonane z materiałów PCM. Ze względu na wymagania BHP materiały znajdujące się $\mathrm{w}$ kontakcie $\mathrm{z}$ wodą użytkową muszą być bezpieczne dla zdrowia, stąd dobór materiałów PCM do takich zastosowań powinien szczególnie uwzględniać ich nietoksyczność. W przypadku materiałów, dla których istnieje ryzyko wystąpienia reakcji z wodą użytkową, stosuje się specjalne warstwy buforowe, izolujące materiał PCM od czynnika roboczego. Materiały zmiennofazowe niewykazujące toksyczności w kontakcie z innymi ośrodkami to głównie parafina. Należy zaznaczyć, że materiały te w większości charakteryzują się niskimi wartościami parametrów cieplnych, w tym głównie przewodności cieplnej.

Celem pracy było zbadanie właściwości termicznych i fizycznych materiałów PCM przeznaczonych do zastosowania w przemysłowych procesach akumulacji ciepła. W ramach pracy zostały wykonane pomiary przewodności, dyfuzyjności cieplnej, ciepła właściwego oraz gęstości. Badane materiały to: wosk plastyczny, cerezyna niskotopliwa oraz ksylitol i erytrytol.

\section{Pomiary cieplne}

W celu analizy przydatności materiałów PCM jako wypełnienia akumulatorów ciepła dokonano pomiarów następujących parametrów cieplnych: współ- 
czynnika przewodzenia ciepła, dyfuzyjności cieplnej, pojemności cieplnej, gęstości oraz oporu cieplnego. Pomiary przeprowadzono dla stanu sypkiego materiałów PCM, następnie materiały te stopiono i odlano z nich próbki, które również przebadano.

Tabela 1. Wykaz ważniejszych oznaczeń

Table 1. Nomenclature

\begin{tabular}{|c|l|}
\hline Symbol & \multicolumn{1}{c|}{ Opis } \\
\hline$\lambda$ & współczynnik przewodzenia ciepła, $\mathrm{W} /(\mathrm{m} \cdot \mathrm{K})$ \\
\hline$a$ & współczynnik dyfuzyjności cieplnej, $\mathrm{m}^{2} / \mathrm{s}$ \\
\hline$c$ & ciepło właściwe, $\mathrm{J} /(\mathrm{kg} \cdot \mathrm{K})$ \\
\hline$c_{v}$ & ciepło właściwe odniesione do $\mathrm{m}^{3}, \mathrm{~J} /\left(\mathrm{m}^{3} \cdot \mathrm{K}\right)$ \\
\hline$\rho$ & gęstość, $\mathrm{kg} / \mathrm{m}^{3}$ \\
\hline$R$ & rezystancja termiczna właściwa, $\mathrm{m} \cdot \mathrm{K} / \mathrm{W}$ \\
\hline$T_{t}$ & temperatura topnienia, ${ }^{\circ} \mathrm{C}$ \\
\hline$T$ & temperatura pomiaru, ${ }^{\circ} \mathrm{C}$ \\
\hline
\end{tabular}

W pracy dokonano pomiaru właściwości termofizycznych takich materiałów, jak: erytrytol, ksylitol, cerezyna oraz wosk plastyczny. Erytrytol jest to organiczny związek chemiczny. Jest on dodatkiem do żywności stosowanym jako substancja słodząca. Erytrytol naturalnie występuje w niewielkich ilościach w wielu owocach, w niektórych porostach i wodorostach. Widok próbki erytrytolu w stanie sypkim przedstawiono na rys. 1.

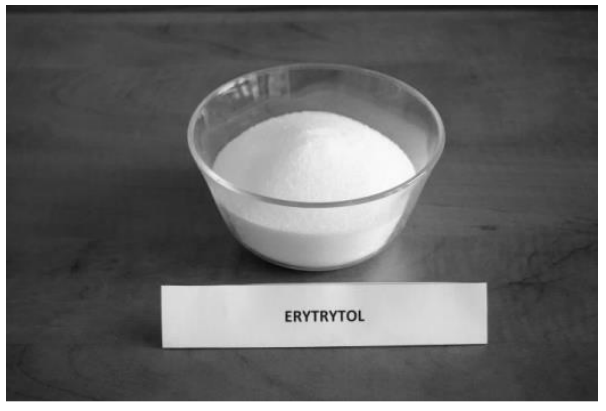

Rys. 1. Erytrytol w stanie sypkim

Fig. 1. Erythritol in powdered state

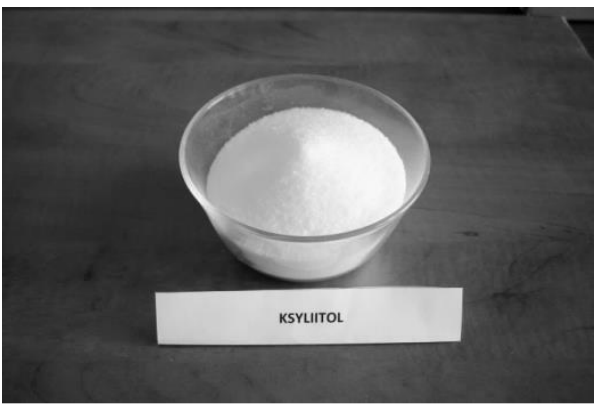

Rys. 2. Ksylitol w stanie sypkim

Fig. 2. Xylitol in powdered state

Ksylitol jest to organiczny związek chemiczny zaliczany do grupy alkoholi polihydroksylowych (cukrowych). Stosowany jest głównie w przemyśle spożywczym do słodzenia, jako dodatek do żywności, głównie gum do żucia i cukierków, ze względu na działanie przeciwpróchnicze. Zaleca się go również diabetykom, 
ponieważ jest metabolizowany z niewielkim udziałem insuliny. Widok próbki ksylitolu w stanie sypkim przedstawiono na rys. 2.

Cerezyna jest to oczyszczony wosk ziemny - biała, bezwonna masa, składająca się $\mathrm{z}$ wyższych węglowodorów nasyconych o temperaturze topnienia w zakresie $60-80^{\circ} \mathrm{C}$, przypominająca wosk pszczeli. Wykorzystuje się ją do wyrobu świec, wosków modelowych, past do butów, jako masy izolacyjne w elektrotechnice oraz jako zagęszczający i antykorozyjny dodatek do smarów stałych (rys. 3.).

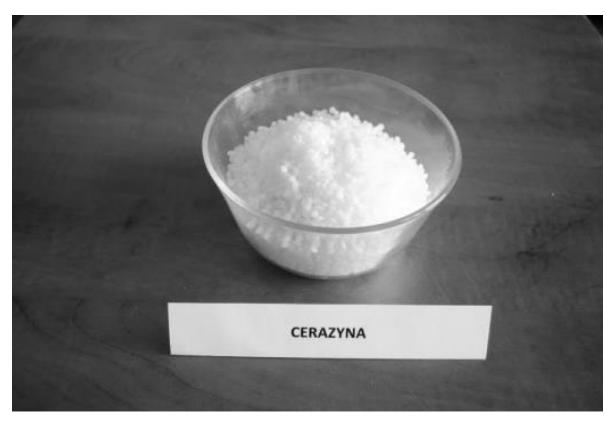

Rys. 3. Cerezyna w stanie sypkim

Fig. 3. Ceresin in powdered state

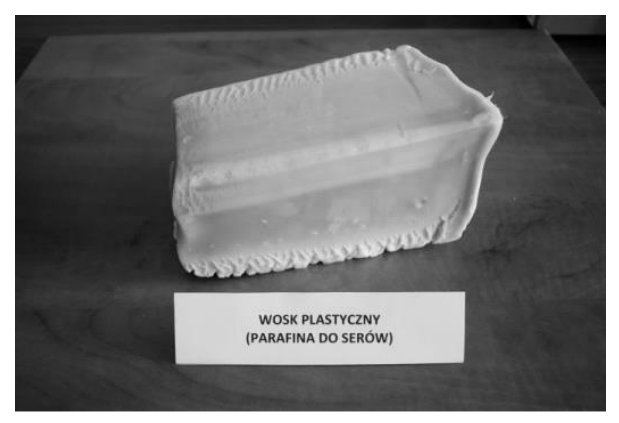

Rys. 4. Wosk plastyczny

Fig. 4. Plastic wax

Wosk plastyczny jest wytwarzany na bazie rafinowanych surowców parafinowych oraz wosku pszczelego (rys. 4.). Stosuje się go w przemyśle mleczarskim do powlekania serów dojrzewających. Chroni ser przed wysuszeniem, zanieczyszczeniami i drobnoustrojami.

\section{Opis aparatury badawczej}

Pomiary parametrów cieplnych zostały wykonane miernikiem KD2 PRO z sondą dwuigłową SH-1, umożliwiającym pomiar metodą gorącego drutu. Analizator KD2 PRO jest ręcznym, przenośnym miernikiem do pomiaru właściwości termicznych gleb, materiałów stałych, sypkich, półpłynnych i płynnych. Zestaw składa się z miernika i czujników, które wprowadza się w badany materiał. Czujniki jednoigłowe służą do pomiaru wyłącznie współczynnika przewodzenia oraz oporu cieplnego. Czujnik dwuigłowy umożliwia pomiar współczynnika przewodzenia ciepła $\lambda$ w zakresie 0,02-2,00 W/(m·K), dyfuzyjności cieplnej $a$ w zakresie 0,1-1,0 $\mathrm{mm}^{2} / \mathrm{s}$ oraz ciepła właściwego odniesionego do objętości $c_{\mathrm{v}} \mathrm{W}$ zakresie $0,5-4,0 \mathrm{MJ} /\left(\mathrm{m}^{3} \cdot \mathrm{K}\right)$. Błąd pomiaru opisywanych parametrów wynosi $\pm 10 \%$. Sonda dwuigłowa umożliwia pomiar w zakresie temperatury od -50 do $150^{\circ} \mathrm{C}$. 
Właściwości cieplne erytrytolu, ksylitolu i cerezyny w stanie stałym sypkim zmierzono przez umieszczenie sondy w różnych miejscach badanych próbek. Pomiary w stanie stałym zostały przeprowadzone po wcześniejszym stopieniu materiałów i wykonaniu odlewów, w których po zastygnięciu było możliwe wywiercenie dwóch równoległych otworów pod sondę dwuigłową.

Gęstość nasypową badanych materiałów w stanie sypkim zmierzono, używając szklanej kolby laboratoryjnej o pojemności $1000 \mathrm{~cm}^{3}$ o działce elementarnej $10 \mathrm{~cm}^{3}$, w której umieszczono badane próbki, następnie zaś dokonano pomiaru ich masy na wadze elektronicznej Radwag WTC 2000 o zakresie pomiarowym 2000 g oraz rozdzielczości 0,01 g. Gęstość badanych materiałów w stanie stałym wyznaczono przez pomiar objętości cieczy wypartej w wyniku zanurzenia badanych próbek w szklanej kolbie wypełnionej wodą i przez zważenie próbek na wadze elektronicznej.

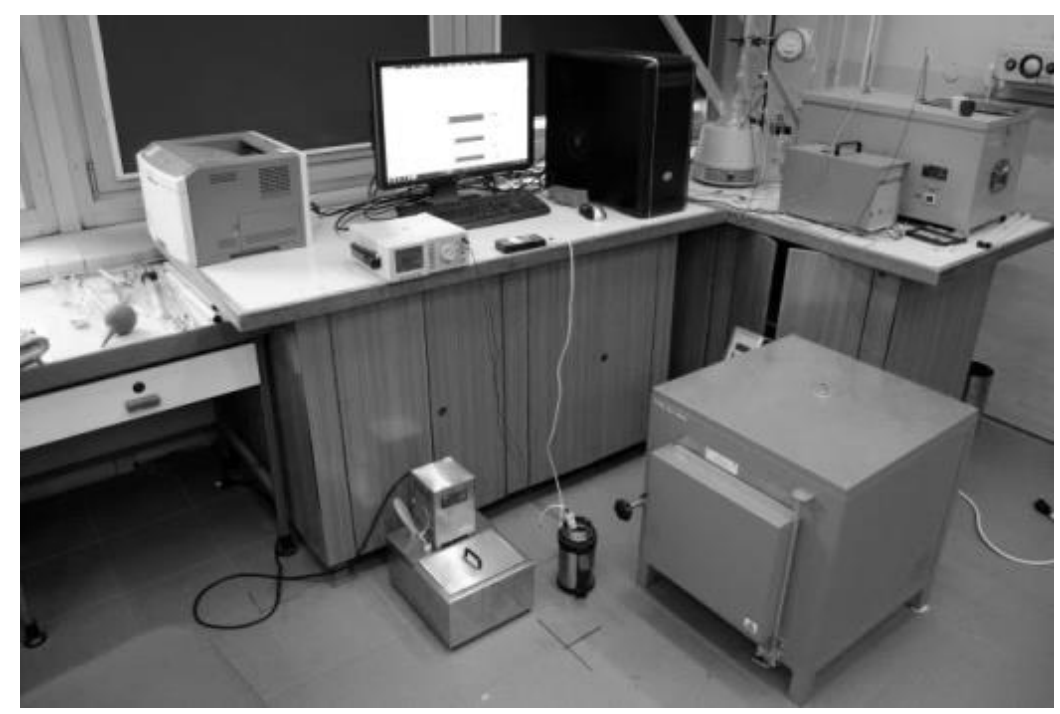

Rys. 5. Stanowisko badawcze do pomiaru temperatury przemiany fazowej

Fig. 5. Set-up for measuring the phase change temperature

Widok stanowiska badawczego do pomiaru temperatury topnienia badanych próbek przedstawia rys. 5. Próbki zostały stopione w piecu muflowym Czylok SM-2002. Do pomiaru temperatury próbki wykorzystano termoparę typu K, której zimny koniec był umieszczony w punkcie topnienia lodu. Pomiar siły termoelektrycznej z termopary odbywał się za pomocą multimetru Appa 207. Dane pomiarowe zapisywano automatycznie w plikach tekstowych. 


\section{Wyniki pomiarów}

Pomiary parametrów cieplnych próbek zostały przeprowadzone dziesięciokrotnie, każdorazowo ze zmianą umiejscowienia sondy w badanej próbce. Następnie obliczano wartości średnie parametrów, które zaprezentowano w tab. 2. i 3 .

Tabela 2. Wyniki badań parametrów termofizycznych materiałów w stanie stałym

Table 2. Results of research on thermo-physical parameters of solid materials

\begin{tabular}{|l|c|c|c|c|}
\hline \multicolumn{1}{|c|}{-} & Erytrytol & Ksylitol & Cerazyna & Wosk plastyczny \\
\hline Stan próbki & ciało stałe & ciało stałe & ciało stałe & ciało stałe \\
\hline$T,{ }^{\circ} \mathrm{C}$ & 25,73 & - & 22,89 & 23,18 \\
\hline$\lambda, \mathrm{W} /(\mathrm{m} \cdot \mathrm{K})$ & 0,647 & - & 0,277 & 0,288 \\
\hline$a, \mathrm{~mm}^{2} / \mathrm{s}$ & 0,325 & - & 0,114 & 0,1 \\
\hline$c_{v}, \mathrm{~J} /\left(\mathrm{m}^{3} \cdot \mathrm{K}\right)$ & $1,99 \cdot 10^{6}$ & - & $2,43 \cdot 10^{6}$ & $2,88 \cdot 10^{6}$ \\
\hline$c, \mathrm{~J} /(\mathrm{kg} \cdot \mathrm{K})$ & 1393 & - & 2706 & 3168 \\
\hline$R, \mathrm{~cm} \cdot \mathrm{K} / \mathrm{W}$ & 154,6 & - & 352,2 & 348,4 \\
\hline$\rho, \mathrm{kg} / \mathrm{m}^{3}$ & 1429 & - & 898 & 909 \\
\hline$T_{t},{ }^{\circ} \mathrm{C}$ & 118 & 90 & - & - \\
\hline
\end{tabular}

Tabela 3. Wyniki badań parametrów termofizycznych materiałów w stanie stałym sypkim

Table 3. Results of research on thermo-physical parameters of powdered materials

\begin{tabular}{|l|c|c|c|}
\hline \multicolumn{1}{|c|}{-} & Erytrytol & Ksylitol & Cerazyna \\
\hline Stan próbki & sypki & sypki & sypki \\
\hline$T,{ }^{\circ} \mathrm{C}$ & 24,13 & 24,31 & 25,70 \\
\hline$\lambda, \mathrm{W} /(\mathrm{m} \cdot \mathrm{K})$ & 0,176 & 0,175 & 0,211 \\
\hline$a, \mathrm{~mm}^{2} / \mathrm{s}$ & 0,134 & 0,129 & 0,095 \\
\hline$c_{v}, \mathrm{~J} /\left(\mathrm{m}^{3} \cdot \mathrm{K}\right)$ & $1,32 \cdot 10^{6}$ & $1,36 \cdot 10^{6}$ & $2,23 \cdot 10^{6}$ \\
\hline$c, \mathrm{~J} /(\mathrm{kg} \cdot \mathrm{K})$ & 1502 & 1628 & 4607 \\
\hline$R, \mathrm{~cm} \cdot \mathrm{K} / \mathrm{W}$ & 567,8 & 574,4 & 476,1 \\
\hline$\rho, \mathrm{kg} / \mathrm{m}^{3}$ & 879 & 832 & 484 \\
\hline
\end{tabular}

\section{Dyskusja wyników}

Wartości współczynników przewodzenia ciepła badanych materiałów porównano na rys. 6. Najwyższą wartość współczynnika przewodzenia ciepła posiada erytrytol $\lambda=0,647 \mathrm{~W} /(\mathrm{m} \cdot \mathrm{K})$, drugim materiałem o najwyższej wartości badanego współczynnika jest wosk plastyczny $\lambda=0,288 \mathrm{~W} /(\mathrm{m} \cdot \mathrm{K})$. Najniższe wartości współczynnika przewodzenia ciepła posiadają słodziki w stanie sypkim, 
tj. erytrytol $\lambda=0,176 \mathrm{~W} /(\mathrm{m} \cdot \mathrm{K})$ oraz ksylitol $\lambda=0,175 \mathrm{~W} /(\mathrm{m} \cdot \mathrm{K})$. Jak można zauważyć, wartości współczynników przewodzenia ciepła badanych materiałów we wszystkich przypadkach są mniejsze od $1 \mathrm{~W} /(\mathrm{m} \cdot \mathrm{K})$, są to zatem materiały źle przewodzące ciepło. Porównując otrzymane wyniki przewodności cieplnej badanych materiałów PCM do materiałów konstrukcyjnych stosowanych w budowie wymienników ciepła, np. stali $(0,5 \% \mathrm{C}) 54 \mathrm{~W} /(\mathrm{m} \cdot \mathrm{K})$, aluminium $237 \mathrm{~W} /(\mathrm{m} \cdot \mathrm{K})$ czy miedzi $398 \mathrm{~W} /(\mathrm{m} \cdot \mathrm{K})$ [6], można stwierdzić, że badane materiały zmiennofazowe posiadają przewodność cieplną mniejszą o co najmniej dwa rzędy wielkości.

Na rysunku 7. zaprezentowano wartości współczynnika dyfuzyjności cieplnej badanych materiałów. Najwyższą wartość tego współczynnika posiada erytrytol $a=0,325 \mathrm{~mm}^{2} / \mathrm{s}$, najniższą natomiast cerezyna w stanie sypkim $a=0,114$ $\mathrm{mm}^{2} / \mathrm{s}$, a następnie wosk plastyczny $a=0,1 \mathrm{~mm}^{2} / \mathrm{s}$. Porównując uzyskane dane pomiarowe z danymi dla materiałów, takich jak stal $(0,5 \% \mathrm{C}) a=14,7 \mathrm{~mm}^{2} / \mathrm{s}$, aluminium $a=96,1 \mathrm{~mm}^{2} / \mathrm{s}$ lub miedź $a=116 \mathrm{~mm}^{2} / \mathrm{s}$ [6], można stwierdzić, że badane materiały charakteryzują się niskim współczynnikiem dyfuzyjności cieplnej (o dwa, a nawet trzy rzędy wielkości). Materiały te wykazują zatem małą skłonność do wyrównywania temperatury podczas nagrzewania lub chłodzenia.

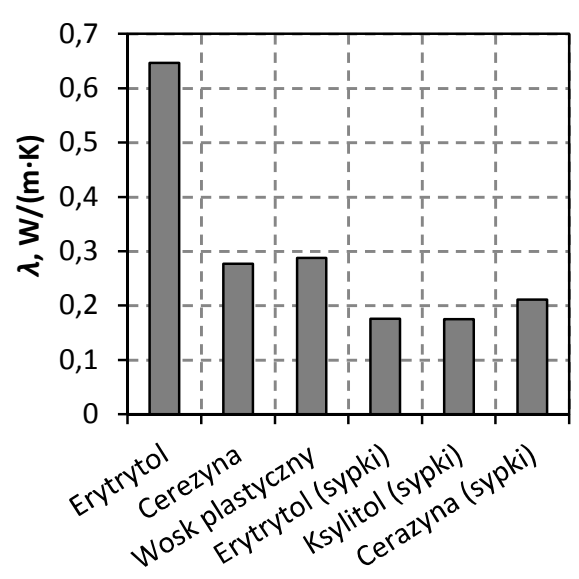

Rys. 6. Współczynnik przewodzenia ciepła

Fig. 6. Thermal conductivity

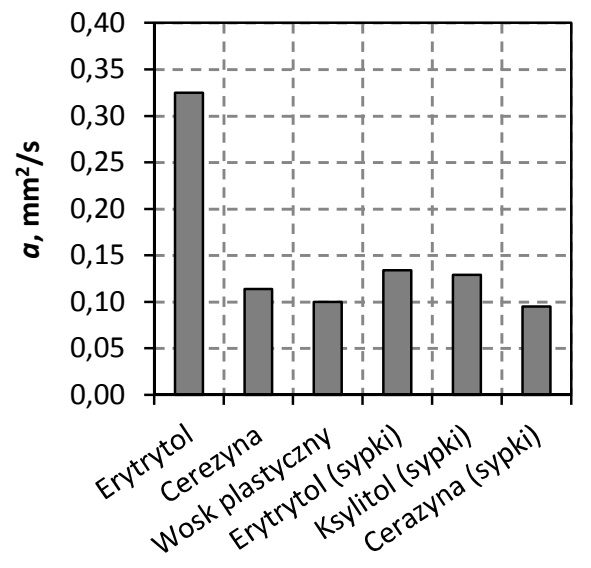

Rys. 7. Dyfuzyjność cieplna

Fig. 7. Thermal diffusivity

Porównanie wartości ciepła właściwego badanych materiałów PCM przedstawiono na rys. 8 . $\mathrm{Z}$ wykresu można odczytać, że najwyższą wartość ciepła właściwego ma cerezyna w stanie sypkim $c=4607 \mathrm{~J} /(\mathrm{kg} \cdot \mathrm{K})$, a następnie wosk plastyczny $c=3168 \mathrm{~J} /(\mathrm{kg} \cdot \mathrm{K})$. Najniższą wartość ma erytrytol $\mathrm{w}$ stanie stałym $c=1393 \mathrm{~J} /(\mathrm{kg} \cdot \mathrm{K})$. Intersującym parametrem okazuje się być objętościowe ciepło właściwe (odniesione do jednego metra sześciennego). W przypadku stosowania 
materiału PCM do wypełnienia zasobnika akumulacyjnego jest to nawet ważniejszy parametr niż masowe ciepło właściwe. Wartości tego ciepła podano na rys. 9. Najwyższą wartość ciepła właściwego odniesionego do $1 \mathrm{~m}^{3}$ ma wosk plastyczny $c_{v}=2,9 \mathrm{MJ} /\left(\mathrm{m}^{3} \cdot \mathrm{K}\right)$, a następnie cerezyna $c_{v}=2,43 \mathrm{MJ} /\left(\mathrm{m}^{3} \cdot \mathrm{K}\right)$.

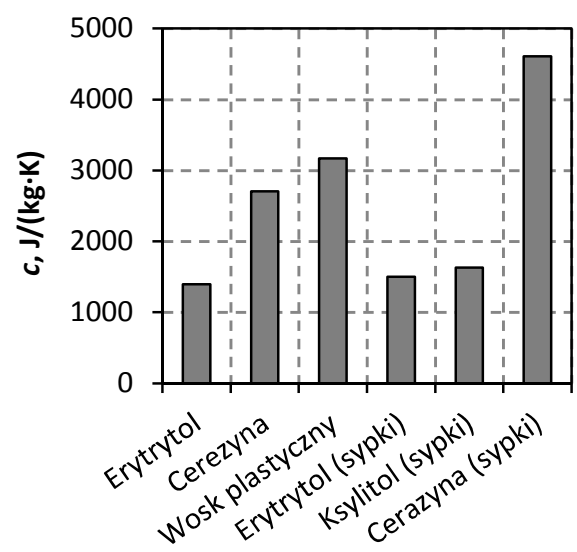

Rys. 8. Ciepło właściwe

Fig. 8. Specific heat

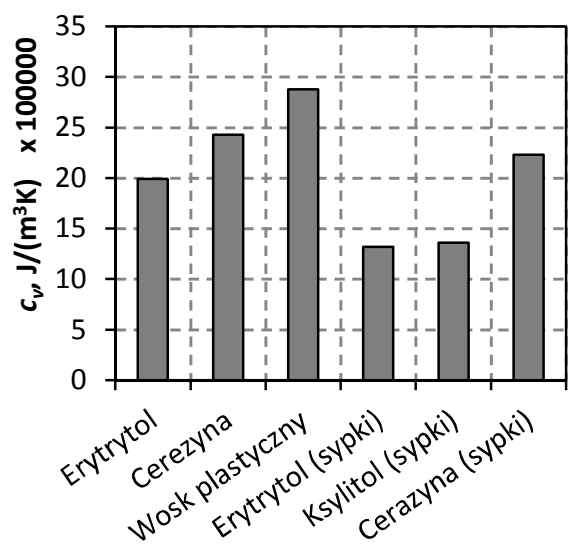

Rys. 9. Ciepło właściwe odniesione do $1 \mathrm{~m}^{3}$

Fig. 9. Specific heat related to $1 \mathrm{~m}^{3}$

\section{Podsumowanie}

W pracy zaprezentowano wyniki badań przewodności, dyfuzyjności cieplnej, oporu cieplnego oraz ciepła właściwego wybranych materiałów zmiennofazowych. Zmierzono gęstość nasypową oraz gęstość materiału w stanie stałym pełnym. Dodatkowo dokonano pomiaru temperatury topnienia materiałów krystalicznych, takich jak erytrytol oraz ksylitol. Ciekawostką jest to, że ksylitol podgrzewany w piecu uległ stopieniu $\mathrm{w}$ temperaturze około $90^{\circ} \mathrm{C}$, ale nie skrystalizował nawet $\mathrm{w}$ temperaturze otoczenia. Wynika to $\mathrm{z}$ faktu, że materiał ten charakteryzuje się bardzo dużą wartością przechłodzenia. Najwyższą wartość współczynnika przewodzenia ciepła oraz współczynnika dyfuzyjności cieplnej wśród badanych materiałów wykazuje erytrytol: $\lambda=0,647 \mathrm{~W} /(\mathrm{m} \cdot \mathrm{K}), a=0,325 \mathrm{~mm}^{2} / \mathrm{s}$.

Uzyskane wartości parametrów termofizycznych badanych materiałów są o około dwa rzędy mniejsze niż dla stali węglowej, z której najczęściej wykonuje się zbiorniki akumulacyjne. Układy odzysku ciepła odpadowego najczęściej pracują $\mathrm{w}$ stanach nieustalonych, $\mathrm{tj}$. podczas ładowania następuje podgrzanie, a podczas rozładowania - ochładzanie materiału PCM, gdzie dodatkowo dochodzi do przemiany fazowej, dlatego bardzo ważna jest znajomość współczynnika przewodzenia i dyfuzyjności cieplnej. Aby układ odzysku energii odpadowej pracował efektywnie, a procesy magazynowania i odbioru ciepła przebiegały stosun- 
kowo szybko, należy zastosować specjalne rozwiązania konstrukcyjne zapewniające duże pole powierzchni wymiany ciepła, gdzie poszczególne warstwy materiału zmiennofazowego mają małą grubość.

Prowadzone badania nie wyczerpują problemów oceny przydatności materiałów PCM do akumulacji ciepła. Autorzy przewidują dalsze badania, mające na celu pomiar ciepła przemiany fazowej na skaningowym kalorymetrze różnicowym DSC. Dopiero zestawienie otrzymanych wyników pomiarów, tj. ciepła właściwego oraz ciepła przemiany fazowej, mogą pomóc przy typowaniu materiałów PCM do konkretnego zastosowania w akumulatorze ciepła.

\section{Literatura}

[1] Kenisarin M.: High-temperature phase change materials for thermal energy storage, Renewable Sustainable Energy Reviews, 14 (2010) 955-970.

[2] Aneke M., Wang M.: Energy storage technologies and real life applications - A state of the art rewiev, Applied Energy, 179 (2016) 350-377.

[3] Pielichowska K., Pielichowski K.: Phase change materials for thermal energy storage, Progress Mater. Sci., 65 (2014) 67-123.

[4] Chadel S.S., Agarwal T.: Rewiev of current state of research on energy storage, toxicity, health hazards and commercialization of phase changing materials, Renewable Sustainable Energy Reviews, 67 (2017) 581-596.

[5] Diarce G., Gandarias I., Campos-Celador A., Garcia-Romero A., Griesser U.J.: Eutectic mixtures of sugar alcohols for thermal energy storage in the $50-90^{\circ} \mathrm{C}$ temperature range, Solar Energy Mater. Solar Cells, 134 (2015) 215-226.

[6] Lienhard J.H.: A heat transfer textbook, Courier Corporation, 2013.

\section{THERMO-PHYSICAL INVESTIGATIONS OF PHASE CHANGE MATERIALS IN THE ASPECT OF THEIR APPLICATION IN SYSTEMS OF WASTE HEAT RECOVERY}

\section{S u m m a r y}

This paper presents the results of experimental investigation of thermophysical properties of selected phase change materials (PCM). It is essential for design heat-storage devices which utilize such materials. The basis of presented investigation was the concept of heat-storage device in cooperation with waste heat recovery unit. The investigated parameters were: thermal conductivity, diffusivity, specific heat and density. The following materials were tested: plastic wax, ceresin, xylithol and erythritol. Thermophysical parameters were obtained with the use of transient hot wire method. To investigate the thermal properties of materials the hot wire method was used.

Keywords: phase change material, specific heat, thermal conductivity, thermal diffusivity

DOI: $10.7862 / \mathrm{rm} .2018 .06$

Otrzymano/received: 10.01 .2018

Zaakceptowano/accepted: 23.02 .2018 
